\title{
DA FEITIÇARIA À LUTA POR DIREITOS. QUAL O LUGAR DOS AFETOS NO TRABALHO ETNOGRÁFICO?
}

\author{
Tiago Lemões ${ }^{1}$
}

\section{Considerações iniciais}

A antropologia deve muito ao que Bronislaw Malinowski (1922) construiu em torno da sistematização do trabalho de campo e da etnografia. A qualquer neófito em antropologia aconselha-se que faça observação participante, que deixe de lado seu caderno de notas e participe das ações e interações promovidas por seus interlocutores. $\mathrm{Na}$ maioria das monografias, teses e dissertações antropológicas, a problematização e caracterização metodológica das investigações consagram estas clássicas orientações como elementos primordiais que caracterizam um verdadeiro trabalho antropológico, por meio do qual a voz do outro se faz presente, assim como a lógica de suas dinâmicas de ação, significação e interação.

Estamos absolutamente cientes de que devemos observar e participar, captar os ossos, a carne e o sangue da vida social; de que precisamos olhar, ouvir e escrever limpando possíveis ruídos (Cardoso de Oliveira, 2000), assim como estranhar o familiar e familiarizar o exótico, considerando a constante realocação destas operações cognitivas (Velho, 1987); compreender o ponto de vista do outro, entendendo-o como sujeito amarrado à teias de significados tecidas por suas próprias mãos, e tentar ler um estranho e desbotado manuscrito culturalmente redigido pelos nativos (Geertz, 1873). Ou mesmo elaborar um relato etnográfico que contemple a relação dialógica entre pesquisador e interlocutor, abrindo espaço para um texto polifônico e ilusoriamente cerrando as portas para uma perversa autoridade etnográfica, que nunca deixa de se manifestar (Clifford, 1998).

São, de fato, orientações valiosas, dentre muitas outras contextualmente construídas, que particularizam a antropologia e fazem com que ela seja uma disciplina de diálogo com o outro, ou seja, com outras possibilidades de compreensão do mundo. Os procedimentos adotados metodologicamente, embora sigam determinados preceitos básicos, possuem uma margem incerta de adequação que subjaz à singularidade de relações estabelecidas entre pesquisador e interlocutor, às negociações entre eles

\footnotetext{
${ }^{1}$ Doutorando em Antropologia Social pela Universidade Federal do Rio Grande do Sul, Brasil, com estágio sanduíche na Université Paris 8, Vinennes Saint-Denis, França. Bolsista CAPES/PDSE.
} 
firmadas para que o diálogo seja possível e, sobretudo, à especificidade dos preceitos que animam e mobilizam os atores sociais com os quais o antropólogo se engaja. Ainda assim, as reflexões podem variar entre uma etnografia na qual o social impera em suas generalizações sobre o que as pessoas pensam e dizem, uma demasiada atenção à subjetividade do próprio pesquisador ou mesmo um trabalho politicamente engajado que pretende dar voz aos silenciados e estigmatizados - todas estas possibilidades assentadas em trabalho de campo em que a observação participante (o envolvimento direto com as dinâmicas relacionais, somando-se às entrevistas) fornece $\mathrm{o}$ tom metodológico.

Nesse debate, Cláudia Fonseca (1998) já nos alertou sobre o encontro tenso, promovido pelo emprego do método etnográfico, entre a perspectiva sociológica (que de certa forma reifica o social) e o individualismo metodológico, que em muito sacraliza o indivíduo. $\mathrm{Na}$ argumentação da antropóloga, tanto a demasiada investida em apressadas interpretações generalizantes, que buscam nos informantes os traços representativos de algum tipo estatístico e que não fornecem dados mínimos sobre o enquadramento histórico e social das pessoas (idade, gênero, geração, educação e classe social); quanto o peso excessivo e restrito à dimensão subjetiva da relação pesquisador-interlocutor, comprometem qualquer tentativa de produção etnográfica que contribua efetivamente para a reflexão antropológica. No tocante à ênfase na reflexividade, Fonseca infere que é quando a subjetividade do autor assume centralidade analítica que os riscos em apresentar os informantes como sujeitos genéricos e ahistóricos, são iminentes. Em sua acepção, é somente após situar as pessoas dentro de um contexto histórico e social que o movimento que vai do particular ao geral possibilita a constituição de um relato etnográfico preenchido e enriquecido não somente por situações de entrevistas, mas também - e principalmente - pelo engajamento do pesquisador na observação participante, através da qual ele acessa determinados elementos que revelam normas sociais, atitudes corporais, critérios morais, estéticos e valorativos. Seria na tentativa de desvelar uma relação sistêmica entre estes múltiplos planos da vida social que os etnógrafos lançam mão da observação participante, em atenção a outras linguagens da vida cotidiana que não aquela restrita ao discurso localizado em situação de entrevista formal (Fonseca, 1998). 
Com estas assertivas fica claro que dar conta da complexidade dos sujeitos que estudamos e com os quais nos envolvemos numa relação múltipla e quase sempre ambígua, está muito além de restritas considerações sobre subjetividades relacionais ou de tentativas que buscam confirmar na prática teorias formuladas no mundo das ideias. Mas ao nos afastarmos de uma discussão sobre caminhos e etapas necessárias à constituição de um relato etnográfico e nos aproximarmos de um debate atento aos dilemas que a observação participante potencializa e às posições críticas sobre o que ainda é o seu principal campo de sistematização da vida social - a cultura - percebemos que a antropologia, como uma disciplina que está sempre revendo suas formulações teórico-metodológicas, não passou imune às críticas direcionadas justamente ao princípio de aplicação que lhe é mais caro: a observação participante e, num plano mais abstrato e mais caro ainda, à própria noção de cultura, a qual vem formulando e reformulando há mais de um século - selecionando aspectos da multiplicidade humana para encontrar o mínimo de regularidade, ainda que assuma seu caráter dinâmico e processual (Kosby, 2009). Aqui a relação entre os usos consagrados da observação participante e o manejo do conceito de cultura parece ser mais estreita do que pensamos. Veremos isso na próxima sessão deste artigo.

Por agora, esclareço que é a partir de uma atenção vigilante às implicações da observação participante, potencializada pela noção de afecção, desenvolvida por FavretSaada (1977) em etnografia sobre a feitiçaria em uma comunidade rural francesa e discutida por Márcio Goldman (2006) em suas pesquisas sobre blocos afros na Bahia, que localizo os argumentos desenvolvidos neste texto. A noção de afecção, no sentido que Favret-Saada concede ao termo, refere-se a um conjunto de intensidades que ultrapassa o trabalho tradicional com a representação dos outros e nos reporta para experiências que nos colocam no lugar onde as mesmas forças afetam a todos, no contexto de um diálogo não planejado, concedendo "estatuto epistemológico às situações de comunicação involuntária e não intencional” (Favret-Saada, 2005: 160). Ser afetado, nesse sentido, é se permitir envolver, atingir-se pelas intensidades, sentimentos, revoltas e desejos que animam os atores engajados em determinado coletivo social: é, no limite, desprender-se da constante posição analítica em campo, respaldada pela observação participante, e permitir-se assumir lugares múltiplos nos quais nossos interlocutores nos colocam, nos chamam a existir. 
Será a partir da retomada dos argumentos centrais desenvolvidos na etnografia de Fravet-Saada e Marcio Goldman que refletirei sobre os dilemas que enfrentei (e de certa forma ainda enfrento), ao longo do processo de inserção em um contexto de pesquisa marcado pela luta política e pela presença e influência de diferentes agentes sociais e autoridades estatais. Um dos meus argumentos é que uma demasiada atenção à dimensão subjetiva, que tome os dilemas, inseguranças, crises e desafios do antropólogo na relação com os seus interlocutores pode nos revelar muito sobre as interpelações éticas que tal relação suscita, mas também sobre processos distintos de conjugação do observar e do participar. Tais interpelações e processos reflexivos, de certa maneira, questionam a onipresença dos objetivos de constituição de um relato etnográfico focado no delineamento de uma relação sistêmica entre múltiplos planos da vida social e evidenciam algo simples, mas potente: o fato de que, em campo, não somos o tempo todo somente antropólogos preocupados com a descoberta de uma racionalidade encoberta aos atores sociais (Oliveira Filho, 2009), mas somos chamados a existir em muitos outros papéis pela própria força e vontade política dos grupos envolvidos; e mesmo antes de qualquer uma destas múltiplas posições em campo, somos e trazemos potencialidades infinitas de sentir, ver, mudar e refletir sobre a forma como compreendemos e dinamizamos o mundo com as pessoas que estudamos (e que também nos estudam à sua maneira).

Especificamente, tenho me engajado, há dois anos, em pesquisa etnográfica atentando para as relações entre pessoas em situação de rua e agentes estatais engajados nos processos de mobilização política e de reivindicação de direitos. Este mergulho ocorre no universo da militância política no Movimento Nacional da População de Rua (MNPR-RS), em sua base regional em Porto Alegre, onde atuo acompanhando e participando de atos públicos, reuniões, seminários, audiências públicas, envolvendome, também, em interações cotidianas com os militantes, para além destas arenas de mobilização. A partir deste contexto, o ponto específico que anima minhas reflexões neste texto se refere ao tenso processo de inserção, em campo, de um pesquisador que, em explícito desconforto com certos discursos e práticas normativas que pareciam conduzir uma determinada forma de produzir política entre militantes, agentes estatais e pessoas em situação de rua, precisou experimentar de uma forma mais extremada os dilemas já clássicos no debate disciplinar: aquele atinente aos papéis do pesquisador e do militante ou os limites e as implicações decorrentes de seus cruzamentos. 
A partir de uma aproximação com etnografias alhures, que fizeram das relações de afecção um campo central de reflexão etnográfica, descreverei, então, as experiências que me permitiram, de forma quase involuntária, lidar com os desconfortos de minha presença em campo e as crises a eles vinculadas, relacionadas tanto às concepções políticas que jaziam no rol de valores e preceitos que trazia em minhas experiências com população em situação de rua, quanto pela lógica própria com a qual o MNPR-RS conduzia suas ações políticas. Será neste ponto que o leitor verá que foi somente com o meu envolvimento pessoal nas investigações do suposto assassinato de um morador de rua, perpetrado por quatro policiais, que as figuras do antropólogo e do militante se cruzaram - não sem conflitos, não sem crises e mal-estar - mas o suficiente para constituir não só um rito de passagem e reflexões sobre particularidades relacionais com as pessoas, mas principalmente para iluminar uma parte importante das formas de produzir política em arenas de intensa interlocução estatal.

Assim, busco apreender a experiência brevemente mencionada acima a partir da premissa de que eu estaria sendo afetado pelas mesmas forças que afetavam os integrantes do MNPR-RS. Antes de adentrar propriamente nos desdobramentos que a noção de afecção permite e nos detalhes de minha inserção em campo, para que o leitor acompanhe o movimento reflexivo que estou propondo, faço a seguir breves apontamentos sobre a construção da noção de cultura e suas implicações em termos de críticas metodológicas. Em seguida, exponho duas experiências etnográficas, conduzidas em pesquisas sobre feitiçaria (na França) e religiões de matriz africana (no Brasil) que radicalizam aquelas críticas e dialogam com a noção de afecção para, finalmente, as colocar em perspectiva com as minhas vivências de inserção no MNPRRS. 


\section{Da cultura construída às verdades operacionais da antropologia}

A dinamicidade que caracteriza a definição moderna de cultura, por excelência, como um conceito antropológico (Laraia, 2009 [1986]) encontra ressonância hoje no campo político, em reivindicações de reconhecimento e afirmação da diferença, articulada ao uso estratégico da cultura e afirmando sua inserção numa dimensão afirmativa e de resistência frente às supostas homogeneizações culturais do mundo globalizado e mundialmente conectado (Sahlins, 2009). Se a antropologia caminha a partir da reformulação de seus arcabouços teóricos e epistemológicos, não seria demasiado surpreendente que antropólogos viessem a constituir críticas potentes ao sentido heurístico, por exemplo, do conceito de cultura, convidando-nos a localizá-lo além de qualquer substancialização.

É o que faz, por exemplo, Roy Wagner, em A invenção da cultura (2010 [1975]), ao demarcar a possibilidade de pensar o conceito para além do funcionalismo, estruturalismo ou mesmo da semiótica, ou seja, para além do pressuposto de unidade funcional. Neste argumento, a cultura é sempre resultado de um encontro, é continuamente a partir da situação de estrangeiro e de contato que ela se inventa. Vale dizer que a discussão que toma a noção de cultura como objeto de reflexão abarca diretamente um debate sobre método, uma vez que para Wagner é na própria operação metodológica que o antropólogo inventa a cultura que estuda, na medida em que o pesquisador percebe o Outro através de seus próprios significados culturais. Essa invenção ocorre por meio da simultaneidade entre observação e aprendizado: ao experimentar outra cultura, se identificam novas potencialidades de viver a vida - e é nessa situação que, no ato de inventar, o antropólogo, além de também inventar a "sua cultura”, inventa a própria noção de cultura.

Sua definição de antropologia, neste contexto reflexivo (dedicado, é importante dizer, às pesquisas em que o antropólogo se relaciona com grupos "externos" à sua sociedade de origem) não poderia ser mais poderosa: trata-se do "estudo do homem como se houvesse cultura" (Wagner, 2010 [1975]: 38). E aqui Wagner elucida as potencialidades da própria situação etnográfica, ao inferir que o pesquisador denomina a situação que estuda como "cultura", antes de tudo, para compreendê-la dentro de seus próprios termos familiares. Tratar-se-ia de um jogo no qual o estudioso inventa a cultura para as pessoas e elas inventam a cultura para ele, operação na qual se familiariza o 
estranho e se estranha o familiar de forma quase inconsciente. Essa interação inventiva, para o autor, é sempre controlada pela falta de consciência do criador sobre seu ato de criação, posto que a invenção não passa de um experimento com os significados culturais do inventor, e o terreno em que tal invenção ocorre, para Wagner, é o da observação, em que o pesquisador se permite a relação de alteridade.

Em uma atmosfera propositiva, Wagner enfatiza que a postura crucial (ética e teórica) a ser tomada consiste em permanecer fiel às implicações de nossa presunção cultural, no sentido de reconhecer que se somos criativos, os outros também o são. Trata-se de lançar mão de uma antropologia reversa, assentada na necessidade e na capacidade de experimentar a relação com nossos interlocutores a partir de seus significados alternativos, ao invés de reduzi-los nos termos de nossas ideologias, ou seja, compreender e reconhecer que os nativos também fazem antropologia na busca de entendimento das diferenças que percebem em seus encontros de alteridade.

A proposição de radicalizar a antropologia do outro também é desenvolvida por Viveiros de Castro (2002), que atenta para a relação assimétrica e perversa entre o discurso nativo e a interpretação do antropólogo. Para o autor, o problema da antropologia é que, tal como afirma Geertz, se somos todos nativos, acabamos sendo sempre mais nativos que os outros, a julgar pelo fato de que o discurso do antropólogo tem uma vantagem epistemológica sobre o discurso nativo: é ele quem bate o martelo na definição da interpretação e do sentido final dado à experiência etnográfica (Viveiros de Castro, 2002). Muito longe de se preocupar com a necessidade de não tomar o discurso nativo como uma versão definitiva da realidade, o autor defende justamente que se permita a esse discurso a produção de efeitos sobre o conhecimento que se ergue sobre si mesmo, no sentido de pensar a visão do Outro como uma teoria epistemologicamente equivalente à teoria antropológica, reconhecendo a ressonância entre diferentes (mas não desiguais) teorizações sobre a realidade. Extremar essas possibilidades, então, é instaurar a oportunidade para que o discurso nativo diga algo e tenha um efeito de conhecimento sobre o discurso antropológico:

O que sucede se, insatisfeitos com a mera igualdade passiva, ou de fato, entre os sujeitos desses discursos, reivindicarmos uma igualdade ativa, ou de direito, entre os discursos eles mesmos? Se a disparidade entre os sentidos do antropólogo e do nativo, longe de neutralizada por tal equivalência, for internalizada, introduzida em ambos os discursos, e assim potencializada? Se, em lugar de admitir complacentemente que somos todos nativos, levarmos às últimas, ou devidas, conseqüências a aposta oposta — que somos todos 'antropólogos' (Wagner 1981: 
36), e não uns mais antropólogos que os outros, mas apenas cada um a seu modo, isto é, de modos muito diferentes? (Viveiros de Castro, 2002: 115).

O desafio está lançado e a tarefa não é fácil. A intenção de conceder estatuto antropológico a todos os sujeitos envolvidos na experiência etnográfica de alteridade esbarra, como bem analisa Oliveira Filho (2009), em certas desconfianças institucionais que insinuam a falta de foco acadêmico e científico, e também nas verdades operacionais da antropologia, a julgar pela defesa de externalidade do olhar antropológico, que valoriza a dissociação dos interesses em jogo, o privilégio de uma descrição baseada na observação, na abstração e no uso de categorias analíticas que permitam explicações distanciadas e mais elaboradas que as teorias nativas (Oliveira Filho, 2009). De certa forma tencionando estas verdades operacionais, as duas experiências etnográficas que apresento a seguir radicalizam a crítica aos pressupostos teórico-metodológicos clássicos da antropologia, buscando entender, de forma preliminar, os avanços e os limites de tais proposições. Penso que a potencialidade e a audácia das experiências de Favret-Saada e Márcio Goldman residem principalmente na postura assumida de conceder estatuto epistemológico não apenas ao discurso do nativo (como inferem Wagner e Viveiros de Castro) mas às relações de afeto involuntárias e não intencionais estabelecidas em campo - justamente aquelas comumente consideradas como um risco ao trabalho acadêmico, pois conduzidas por intensidades outras que não aquelas atinentes ao oficio de antropólogo vigilante, preocupado em remeter tudo ao social e diferenciar observação participante dos episódios de envolvimento vertiginoso com o universo de pesquisa - situações em que são rapidamente aconselhados por seus mestres a buscar uma medida para a externalidade.

O que Favret-Saada propõe é justamente o contrário: dar centralidade às situações nas quais esquecemos ou deixamos de ser, momentânea e involuntariamente, antropólogos. Vejamos, então, com proximidade o motivo pelo qual essa antropóloga entende a observação participante como um obstáculo ao trabalho etnográfico. 


\title{
A feitiçaria e a condicionalidade dos afetos
}

\begin{abstract}
Pois então, eles falaram disso comigo somente quando pensaram que eu tinha sido 'pega' pela feitiçaria, quer dizer, quando reações que escapavam ao meu controle lhes mostraram que estava afetada pelos efeitos reais - freqüentemente devastadores - de tais falas e de tais atos rituais. Assim, alguns pensaram que eu era uma desenfeitiçadora e dirigiram-se até a mim para solicitar o ofício; outros pensaram que eu estava enfeitiçada e conversaram comigo para me ajudar a sair desse estado. Com exceção dos notáveis (que falavam voluntariamente de feitiçaria, mas para desqualificá-la), ninguém jamais teve a idéia de falar disso comigo simplesmente por eu ser etnógrafa (Favret-Saada, 2009: 157).
\end{abstract}

Movida pelo interesse etnográfico nas formas de regulação da violência e do homicídio em sociedades camponesas - em continuidade às pesquisas que realizara sobre a regulação do crime pela instituição da vendetta em pequenas sociedades árabes sem Estado -, Favret-Saada viveu de 1968 a 1971 na região do Bocage de l'Ouest, na França, por conta de um estudo sobre a feitiçaria e suas formas de regulação social. Somente seis anos após finalizar as experiências com a feitiçaria camponesa, sua pesquisa foi finalmente redigida e publicada em Les mots, la mort, les sorts (1977). O tempo (aquele não mensurável por parâmetros usuais) foi fundamental no processo de reflexão inscrito na redação final, mas também na possibilidade mesmo de entrar em contato efetivo com a feitiçaria ainda durante a pesquisa: nos primeiros meses de trabalho de campo, a antropóloga declara que nada era dito pelos seus interlocutores sobre a prática da feitiçaria, a não ser a constante repetição de que ela existia somente entre os atrasados, os tolos e os estagnados no tempo. Com essa experiência sendo reiteradamente negada ou denegada, tudo parecia indicar que o seu projeto de pesquisa estava seriamente comprometido.

Mas além de um tempo que se espera passar para que os nativos se acostumem com a presença do pesquisador, o tempo ao qual Favret-Saada infere em sua etnografia é aquele que constitui uma relação, e não pelo qual se espera a constituição de familiaridade (Goldman, 2005). Se a partir de um determinado momento os discursos e as práticas sobre a feitiçaria passaram a implicar a antropóloga, não foi pela aquisição gradual de familiaridade ou empatia, mas sim pelo fato de que, em primeiro lugar, "parler, en sorcellerie, c'est jamais pour informer. [...] Il est littéralement incroyable d'informer un ethnographe, c'est-à-dire quelqu'un qui assure ne vouloir faire aucun usage de ces informations, qui demande naïvement à savoir pour savoir" (Favret- 
Saada, 1977: 26). Nesse contexto, a palavra é poder, jamais informação. Ela é guerra, pois "il n'ya pas de position neutre de la parole: en sorcellerie, la parole, c'est la guerre. Quiconque en parle est un belligérant et l'ethnographe comme tout le monde. Il n'ya pas de place pour un observateur non engagé” (Idem: 27). A julgar, então, pela potência que a palavra e a informação detinham no sistema de feitiçaria, falar sobre o assunto com apenas uma etnógrafa - de antemão entendida como alguém que baseia seu entendimento do mundo numa dimensão positiva do conhecimento - era uma possibilidade fora de questão, a não ser que essa pesquisadora tivesse sido, de alguma forma, enfeitiçada. E, longe de uma pura e simples estratégia de adequação metodológica, foi exatamente o que aconteceu.

Somente quando Favret-Saada passou a apresentar sintomas que permitiram aos camponeses diagnosticá-la como detentora do dom de desenfeitiçar e, posteriormente, como enfeitiçada, que sua localização, dentro do sistema de feitiçaria (entre feiticeiros, desenfeitiçadores e enfeitiçados - agora ela ocupava alguns destes lugares), abriu caminhos para que uma modalidade específica de comunicação fosse cultivada: aquela movida pelos afetos, pela interação involuntária, sem a intenção de sistematizar a experiência, deixando-se agitar por sensações, percepções e pensamentos agenciados pelos que ocupam um lugar naquele sistema. Foi, de fato, a posteriori, que a autora compreendeu que ter exterioridade, em antropologia, é renunciar conhecer certos discursos, sobretudo aqueles que não podem ser ditos pelos interlocutores - precisam ser vivenciados para que se possa, inclusive, compreender o que os silêncios querem dizer em campo ${ }^{2}$.

\footnotetext{
${ }^{2}$ Com as reflexões que a conduziram a uma ênfase na comunicação permeada por processos de afecção, a pesquisadora em questão reitera que, no fundo, antropólogos como Malinowski, Turner, Van Gennep e Evans-Pritchard compunham uma literatura que parecia ancorar-se num deslizamento de sentidos entre vários termos, tomando a verdade como real, o real como observável e o fato como ato. Prtichard, por exemplo, apesar de ter apontado a lógica interna da bruxaria entre os Azande, circunscrevendo-a num sistema de crenças internamente coerente, capaz de explicar infortúnios e resolver conflitos daí advindos, não deixa de considerar a eficácia das crenças na bruxaria e nos processos divinatórios como absurda, uma explicação de mundo que não pode ser verdadeira, embora algumas vezes, em campo, ele tenha se utilizado de tal sistema para explicar determinados fenômenos. Contudo (e aqui se ancora a crítica de Favret-Saada) este antropólogo, em determinada passagem de sua obra, afirma ter supostamente visto a bruxaria andar nos arredores de suas instalações (Pritchard, 2005), mas não concede maior atenção a isso por considerar a bruxaria uma impossibilidade, afirmação que, para aquela antropóloga, oculta e esteriliza a crítica possível ao próprio pensamento ocidental hegemônico.
} 
É inútil indagar, como bem observa Goldman (2005), se a antropóloga do Bocage francês passou a acreditar que tivesse sido enfeitiçada; ou se teria sido contemplada (pois imersa ainda em sua incólume objetividade científica) pela insistência de um crédulo local em afirmar que feitiços teriam sido lançados contra ela. Não se trata de sorte metodológica ou de crença, como explica a autora, mas de afeto. Isso significa que, como observa Goldman (2005: 150), "basta que os etnógrafos se deixem afetar pelas mesmas forças que afetam os demais para que um certo tipo de relação possa se estabelecer, relação que envolve comunicação muito mais complexa que a simples troca verbal a que alguns imaginam poder reduzir a prática etnográfica". E, nas palavras da própria autora, deixar-se afetar é também acessar outra modalidade de comunicação e de experiência, pois

[...] se for capaz de esquecer que estou em campo, que estou trabalhando, se for capaz de esquecer que tenho meu estoque de questões a fazer... se for capaz de dizerme que a comunicação (etnográfica ou não, pois não é mais esse o problema) está precisamente se dando, assim, desse modo insuportável e incompreensível, então estou direcionada para uma variedade particular de experiência humana - ser enfeitiçada, por exemplo - porque por ela estou afetada (Favret-Saada, 2005: 160).

A partir da noção de afecção, enquanto modalidade de relação e comunicação no trabalho etnográfico, convém expor alguns efeitos mais imediatos sobre a observação participante - operação teórico-metodológica que caracteriza e particulariza a prática etnográfica desde Malinowski. Em princípio, Favret-Saada observa que a relação (ou o corte relacional) entre observação e participação era dinamizada, por seus colegas franceses, de duas formas: pela via ativa, com trabalho de entrevista e observação com informantes pagos; e pela via passiva, de observação de rituais e eventos ligados à feitiçaria. No primeiro caso, quem participa, na verdade, é o informante; no segundo, participar se reduz ao estar lá. A observação supera, aqui, a participação, sobretudo pelo fato de que o mais importante, para aqueles antropólogos, era o dizível e o visto a olho nu desde uma distância centrada entre o participar e o observar.

Mais inquietante que isso, para Favret-Saada, são os efeitos perversos de tais escolhas contidas na literatura sobre feitiçaria (sobretudo anglo-saxã), expressas na correlação entre verdade, real e observável e o seu reverso simétrico: o deslizamento de sentidos entre o erro, o imaginário e o inobservável - uma verdadeira desqualificação da palavra nativa, em promoção daquela do etnógrafo (Favret-Saada, 2005). Foi quando, 
de fato, se viu confrontada pelos seus interlocutores a ocupar um lugar, a ser algo mais do que um antropóloga que, por mais que se esforce em participar, busca sobretudo observar, que um dilema metodológico a conduziu pela oscilação entre dois obstáculos: se participasse, se aceitasse ser afetada pelas mesmas intensidades que afetavam aqueles camponeses, o trabalho de campo poderia tornar-se uma aventura pessoal, algo distinto de um trabalho; mas se investisse na observação, cuja externalidade é condição essencial, nada encontraria para observar. "No primeiro caso, meu projeto de conhecimento estava ameaçado, no segundo, arruinado" (Idem, 2005: 157). Sua escolha foi a ameaça.

Por fim, em um já anunciado diálogo com as ideias de Favret-Saada sobre a etnografia, Marcio Goldman (2005) nota que o trabalho da autora não se encaixa nos dois principais estilos etnográficos contemporâneos, a saber: a apresentação das pessoas, suas ações, o que dizem e supostamente pensam; e a tendência a voltar-se para dentro, caindo num hipersubjetivismo de tipo autobiográfico. O que o estimula nesse caminho, é a certeza de que uma relação de comunicação não intencional e atravessada por afetos pode fazer com que a participação seja levada a sério na antropologia. É com essa posição que Goldman também busca potencializar a discussão sobre o lugar dos afetos na etnografia, especificamente no contexto das religiões de matriz africana e seus cruzamentos com a luta política em terras brasileiras.

\section{O som dos mortos, dos vivos e dos semi-vivos}

As primeiras investidas de Marcio Goldman no trabalho de campo em Ilhéus, sul da Bahia, remontam ao verão de 1983, quando o antropólogo passou três meses em um terreiro afro-religioso no intuito de escrever uma dissertação de mestrado sobre a possessão no candomblé. Mais de dez anos depois, na introdução ao livro $^{3}$ no qual elabora uma teoria etnográfica da política a partir de suas longas e intermitentes experiências em Ilhéus, Goldman afirma que suas relações com os interlocutores do terreiro e da cidade eram atualizadas quando de seus retornos em diferentes etapas de pesquisa ao longo da década de 1990 e nos primeiros quatro anos do século 21. No entanto, foi quando concentrara sua pesquisa de campo no Dilazenze, um dos blocos afros de Ilhéus, buscando entender as relações entre o movimento negro e a vida política

${ }^{3}$ GOLDMAN, Márcio. Como funciona a democracia. Uma teoria etnográfica da política. Rio de Janeiro: Sete Letras, 2006. 
na cidade, que sucessivos eventos, ocorridos a partir da noite do dia 31 de outubro de

1998, quando acompanhara os ensaios do bloco, marcariam definitivamente sua forma

de conceber os múltiplos processos implicados na prática etnográfica. A citação é longa,

mas necessária:

Dona Ilza Rodrigues, a mãe-de-santo de Ewá Tombency Neto, o terreiro de candomblé ligado ao bloco, chamou-me de lado e, explicando que tinha que realizar o despacho dos assentamentos de uma filha-de-santo que morrera recentemente enquanto ela estava em São Paulo, perguntou-me se eu poderia ajudar, transportando em meu carro os objetos rituais da falecida para serem jogados em um rio, ou seja, o despacho. Respondi que, evidentemente, ajudaria, e ela acrescentou que era preciso resolver tudo rapidamente uma vez que Finados estava próximo e não era conveniente que o ritual fosse realizado após o dia dos mortos. Combinamos que no momento adequado ela mandaria me chamar, e recordei, com ela, que em 1983, quando realizara uma pesquisa no terreiro, eu também ajudara a transportar um despacho. Marinho Rodrigues, um dos filhos carnais da mãe-de-santo, ogã do terreiro ${ }^{4}$, um de meus grandes amigos e meu melhor informante em Ilhéus, contoume, então, que a filha-de-santo recém falecida era de Xangô e havia declarado explicitamente que, quando de sua morte, não desejava que o ritual completo fosse realizado; e era por isso, disse ele, que só haveria o despacho dos assentamentos. Ante minha surpresa, explicou-me que alguns fiéis do candomblé fazem esse pedido, que tem que ser respeitado, uma vez que não se deve invocar um espírito que não o deseja ser. Conversávamos ainda sobre os rituais funerários do candomblé quando, por volta das sete e meia, fui chamado para estacionar o carro diante do portão do terreiro. Eu o fiz, abri o porta-malas do carro e, logo, dois ogãs (igualmente filhos carnais da mãe-de-santo) trouxeram uma grande e pesada caixa que depositaram no compartimento. Entramos no carro, junto com duas filhas-desanto que não reconheci naquele momento. Partimos e os ogãs me informaram a direção a seguir; falamos pouco e as duas filhas-de-santo nada. Chegamos ao local desejado: uma ponte em uma estrada meio abandonada no antigo caminho para Itabuna. Paramos, descemos, abrimos o porta-malas, os ogãs pegaram a caixa e se dirigiram, com as filhas-de-santo, para a ponte. Fiquei no carro, esperando e olhando discretamente. Sobre a ponte, jogaram a caixa no rio; quando esta bateu na água, com muito barulho, as duas filhas-de-santo lançaram os gritos de seus orixás, e apenas nesse momento me dei conta de que estavam em transe todo o tempo. Um dos gritos era de Iansã, o outro de Ogum, dois orixás que mantêm relações privilegiadas com os mortos. Um dos ogãs entrou no mato, acendeu as velas que havia levado e, em seguida, os dois sopraram no ouvido das filhas-de-santo, que saíram imediatamente do transe. Nesse momento, escutei ao longe o som de instrumentos de percussão; imaginei, primeiro, serem atabaques, depois algum ensaio de bloco afro ou coisa parecida. Entramos no carro e partimos, evitando retornar pelo caminho por onde fomos a fim de não passar pelo ponto em que o despacho fora lançado. Voltamos para o terreiro onde, no portão de entrada, alguém nos esperava para um rápido ritual de purificação, que se estendeu, aliás, ao interior do automóvel. Assunto aparentemente encerrado, retomei a conversa com Marinho, conversa que logo retornou para os rituais funerários do candomblé. Ele me contou que em 1994, na obrigação dos 21 anos relativos à morte de sua avó (antiga e famosa mãe-de-santo do terreiro), ele levara um despacho exatamente ao mesmo lugar de onde eu acabava de voltar; de repente, disse, começou "a ouvir os atabaques dobrarem", perguntando então aos demais se havia algum terreiro de candomblé por lá, ao que todos responderam que não. De volta ao terreiro, narrou o ocorrido a sua mãe e a outras pessoas mais velhas, que ficaram muito contentes, já que o fato dos atabaques tocarem é um bom sinal, pois significa que os mortos estão aceitando

\footnotetext{
${ }^{4}$ Título concedido aos homens que auxiliam nos terreiros mas que, pela posição que ocupam, não lhes é permitido a possessão por espíritos (GOLDMAN, 2006).
} 
receber em paz o espírito ou a oferenda em jogo. Senti um leve arrepio e disse a meu amigo que eu também ouvira atabaques dobrarem; ele não fez nenhum comentário e mudou de assunto. Percebi, então, que os tambores que eu ouvira simplesmente não eram deste mundo (Goldman, 2006, p.14).

Ingenuidade seria pensar que Goldman, por ser antropólogo, não teria ficado extremamente tentado a conceder, de forma pessoal, uma explicação mística à experiência acima narrada. Contudo, por muito tempo, o que mais lhe preocupou foi encontrar uma maneira de não reduzir o evento a uma das recorrentes anedotas sobre experiências extraordinárias vivenciadas por antropólogos em campo. Antes de tudo, seus anseios demonstravam que, aos poucos, a opção que pretendia seguir dependia de seu esforço em conceder tamanho grau de dignidade ao episódio dos tambores que lhe permitisse relacionar com o trabalho em Ilhéus. Mas antes mesmo de tais esforços analíticos, se fez necessário refutar duas vias explicativas que, em sua visão, impediriam um trabalho sério de reflexão: a afirmação mística de que os tambores tinham sido tocados pelos mortos; e a interpretação materialista, que atribuiria os tambores inevitavelmente ao som produzido pelos vivos. O que, na verdade, Goldman declara é a inutilidade de seguir qualquer uma destas explicações, simplesmente pelo fato de que a experiência foi levada a sério pelo pesquisador, que se viu afetado por intensidades que também afetam seus interlocutores: "a força do acontecimento permitiu, sem dúvida, que se estabelecesse entre nós certa forma de comunicação não-verbal, 'involuntária e não-intencional', condição, talvez, para que outros canais de comunicação mais discursivos e conscientes também se abrissem" (Goldman, 2006:17).

O mais difícil, porém necessário, se anuncia entre os desafios postos pela experiência com os tambores: encontrar uma relação com os interesses que, a princípio, guiavam a estadia do antropólogo em Ilhéus: uma pesquisa sobre política. Somente três anos após a referida experiência e por intermédio de um sonho que o relembrou realisticamente algo (também registrado em seu caderno de campo) que vivera três dias antes de ouvir o misterioso som dos tambores, que as coisas começaram a se enlaçar. $\mathrm{O}$ sonho o reportava para uma conversa com um político local do Partido dos Trabalhadores, de quem, ao tecer um comentário sobre a batucada, obteve em resposta: “eles estão fazendo batucada para não fazer nada". A confirmação, no diário de campo, dessa lembrança onírica também o conectou a um diálogo sobre ritual funerário do candomblé angola, desta vez com um dos filhos carnais da mãe-de-santo que o convidara para ajudar no despacho. Na ocasião, seu interlocutor explicara que o ritual se 
tratava, em parte, de uma luta entre os vivos e os espíritos dos mortos: "os vivos não podem permitir que os mortos toquem e cantem mais alto do que eles, sob a pena de os mortos invadirem o mundo dos vivos, possuírem o corpo dos presentes e até matá-los" (Goldman, 2006: 17).

Foi com a apreensão destas duas conversas com interlocutores diferencialmente posicionados no campo de forças políticas de Ilhéus, que o antropólogo encontrou a ponte que lhe faltara entre os tambores dos mortos e os tambores dos vivos. Isso porque aquela opinião do petista sugeria que os tambores tocados para não fazer nada eram produzidos por seres semi-vivos, vinculando a batucada à falta de consciência política. Ora, em primeiro lugar, a informação de que, no ritual funerário, os vivos não podem permitir que os mortos toquem e cantem mais alto do que eles permite pensar a batucada como forma de luta. Também o tempo de trabalho de campo levado a cabo por Goldman em Ilhéus já evidenciara que a produção da música afro era potencializada muito além de uma preconceituosa afirmação de inércia política. Ao contrário, tal produção "compunha uma das dimensões essenciais dos processos de criação de territórios existenciais que permitem a pessoas discriminadas produzir sua própria dignidade e vontade de viver" (Idem, 2006: 18). Ao fim, os sons tocados pelos vivos e pelos mortos, argumenta o autor, fazem parte de uma mesma experiência, o que explica que somente ao escutar o som dos mortos é que o som dos vivos passaram a fazer outro sentido.

Aqui, vale novamente frisar: estes afetos não se referem a sentimentos, emoções, mas àquilo que afeta e modifica. A experiência de ser afetado e o esforço em conceder estatuto epistemológico ao que, não muito raro, é tratado como viagem mística em trabalhos acadêmicos, são pensados por Goldman como enunciadores de processos de desterritorialização (a partir da escuta dos tambores dos mortos) e de reterritorialização (posterior, graças à leitura dos diários de campo) - movimentos que lhe fizeram não só olhar para outras questões em campo, mas também encontrar um lugar para os afetos na etnografia. Podemos dizer que esse lugar se concentra no cruzamento entre: (i) o reconhecimento da potência da afecção em nos fazer atentar para dimensões antes ignoradas sobre as formas como as pessoas criam e recriam territórios existenciais, cuja apreensão é cada vez mais incompleta quanto mais cartesiano e externo é o olhar do pesquisador; (ii) e as reflexões que estas experiências instigam sobre como conceber o trabalho etnográfico e a relação de alteridade que lhe é subsidiária. 
É assim que a etnografia, como propõe Goldman, pode ser pensada não como procedimento de observação, de conversão (para assumir o ponto de vista do outro) ou de transformação substancial (para tornar-se nativo), mas sim como uma espécie de devir-nativo $^{5}$, ou seja, um movimento pelo qual nos permitimos sair de nossa condição através de uma relação de afetos com uma outra condição, sem que, uma vez afetados por essa realidade outra, nos tornemos, de fato, pertencentes incondicionais a ela. Não se trata de conversão, mas de aceitar que o que acontece aos outros também pode acontecer ao pesquisador - algo aparentemente tão simples e óbvio, mas sempre potente quando se ocupa de nos fazer buscar um lugar diferente para a experiência humana na etnografia.

A intenção de apresentar as duas experiências etnográficas supracitadas não é, de forma alguma, consagrá-las ou sacralizá-las como exemplos impecáveis e incontestes de esforços de reflexão ou tradução de experiências à primeira vista incompreensíveis e incontroláveis. Liliana Porto (2007), por exemplo, pondera que a etnografia de FavretSaada peca ao inicialmente supor a inexistência de bruxos, justificada pela dificuldade de acesso às informações públicas sobre feitiçaria. Nesse caso, a suposição de inexistência de feiticeiros, ainda que opere enquanto princípio de estranhamento, indica que a etnografia no Bocage não problematiza a força dos estigmas sociais que recaem sobre a feitiçaria. E eu acrescentaria: quais seriam, hoje, as implicações éticas em um tipo de trabalho que revela a existência de tal prática entre um determinado coletivo que, ao ocultar, tanto se protege parcialmente da força dos estigmas, quanto preserva a especificidade da existência feiticeira, para a qual a palavra nunca é informação, é sempre luta e poder?

No que se refere, igualmente, ao trabalho de Marcio Goldman, sobretudo no que ele nos ensina sobre a inserção de antropólogos em pesquisas com o campo afroreligioso, poderíamos considerar as análises de Wagner Silva (2004), para quem estas inserções se diversificam desde uma deliberada iniciação religiosa enquanto princípio metodológico de acesso a determinados conhecimentos inacessíveis aos demais; passando pela conversão íntima destes - em que a crença nos orixás é compartilhada -

\footnotetext{
${ }^{5} \mathrm{O}$ conceito de devir é aqui utilizado por Goldman tomando de empréstimo a definição de Felix Guatarri, para quem devir é "um termo relativo à economia do desejo. Os fluxos de desejo procedem por afetos e devires, independentemente do fato de poderem ser ou não rebatidos sobre pessoas, imagens, identificações. Assim, um indivíduo antropologicamente etiquetado masculino pode ser atravessado por devires múltiplos e, em aparência, contraditórios: devir feminino coexistindo com um devir criança, um devir animal, um devir invisível, etc" (Guatarri, 1986:288, apud Goldman, 2006:31).
} 
até uma avaliação ambígua desta relação em atenção aos conflitos entre éticas religiosas diversas ou entre os dilemas de aceitação dos valores religiosos, porém sem adesão subjetiva a eles. Esse envolvimento múltiplo, em parte, é explicado pelo fato de que "a religião dificilmente se 'revela' aos olhos de quem não a experimenta" (Silva, 2004: 29). Mas no caso de Goldman, fica claro que a experiência de afecção não se enquadra numa simples e deliberada estratégia metodológica, muito menos se vale da conversão ou de um esforço em tornar-se nativo. Muito mais do que pensar no que fazer para atingir estas experiências extremadas de afeto, o que se coloca como desafio é o que fazer com elas quando nem sequer se imagina experimentá-las. O inegável é que Goldman e Favret-Saada nos fazem pensar, e muito, sobre a potência que situações como as por eles narradas guardam no tocante à constituição de um lugar central para os afetos em trabalhos etnográficos, concedendo tanto um estatuto epistemológico à afecção (FavretSaada, 2005), quanto um grau de dignidade (Goldman, 2005) que nos permita, também, acessar a compreensão do universo que estudamos de um outro ângulo.

A exposição, a seguir, de minha experiência etnográfica junto à mobilização política da população em situação de rua em Porto Alegre, é uma tentativa de, por um lado, evidenciar contextos distintos nos quais relações de caráter involuntário e nãointencional podem ocorrer, e o quanto a especificidade destes contextos também influenciam a inteligibilidade que atribuímos àquelas experiências; e, por outro, refletir sobre o que tais relações podem revelar sobre as formas de ação e mobilização dos coletivos estudados e como elas podem implicar, em termos éticos, o próprio pesquisador.

\section{A potência de um suposto assassinato}

Em linhas gerais, o estudo que realizei em minha pesquisa de mestrado, finalizada em 2012, problematizou, a partir do método etnográfico, as relações mantidas, criadas e atualizadas por homens e mulheres em situação de rua no centro de Pelotas, extremo-sul do Rio Grande do Sul. Para discutir estas relações, a pesquisa estruturou-se sobre um tríplice enfoque: a continuidade das relações familiares no contexto das ruas; as estratégias de construção e manutenção de vínculos com diferentes personagens no espaço público; e os códigos de sociabilidade que orientam a 
constituição de vínculos entre os pares em situação de rua ${ }^{6}$.

Como é possível de antemão depreender destas primeiras investidas, a dimensão de uma política coletivamente organizada e reivindicatória não se colocava entre os meus interesses, embora ela fosse tencionada constantemente na atuação individual de alguns sujeitos contra os serviços sócio-assistenciais disponíveis na cidade e, já ao final do trabalho de campo, o princípio de uma organização coletiva em torno dos direitos da população em situação de rua começou a fazer parte do diálogo entre alguns interlocutores. Quase dois anos depois, em 2014, quando já ancorava meus estudos em Porto Alegre, soube que, no primeiro fechamento de um dos serviços especializados para o segmento, cartazes foram anexados nos muros da instituição, com mensagens do tipo "morador de rua não é bandido"; "somos a parte menos favorecida, mas temos o nosso direito social”. Em entrevista, a secretária de Justiça Social e Segurança justificou o fechamento do serviço pelo fato de que o público alvo, composto pelos "moradores de rua por necessidade" não estava sendo atendido, uma vez que "a maioria é de pessoas com família e que prefere ficar na rua por opção, porque assim não precisa seguir as regras 7 ".

Era contra afirmações desse tipo e outros tratamentos desrespeitosos vivenciados no interior de instituições de acolhimento e convivência, que eu presenciava a indignação e o enfrentamento de alguns dos meus interlocutores, sempre contra a ação de alguma assistente social, psicólogo ou mesmo os funcionários contratados para garantir a segurança dos espaços institucionais. No texto etnográfico, não dei conta destas situações, pois meus interesses de pesquisa estavam direcionados às redes de afetividade e reciprocidade tecidas especificamente no universo das ruas - atravessadas seja pela continuidade dos laços familiares, pela relação com os pares em situação de rua e com outros agentes (comerciantes, policiais, redutores de danos, grupos caritativos). No entanto, já ingresso no doutorado em antropologia social e, para tal, passando a residir na capital gaúcha, entrei em contato com a base regional do Movimento Nacional da População de $\operatorname{Rua}^{8}$ (MNPR-RS), o que direcionou meus

\footnotetext{
${ }^{6}$ A pesquisa foi publicada em livro e pode ser acessada em LEMÕES, Tiago. A família, a rua e os afetos: uma etnografia da construção de vínculos entre homens e mulheres em situação de rua. São Paulo: NEA, 2013.

${ }^{7}$ FARACO, Camila. Clima de tensão no Centro-pop. Diário Popular, Pelotas, 04 de abril de 2014.

${ }^{8}$ Como culminância das inserções da população em situação de rua no cenário político (que provocam uma pluralização das nomenclaturas, tais como "povo sem casa", "povo de rua" e, por fim, "sofredores de rua") funda-se em 2005, na capital paulista, o Movimento Nacional da População de Rua (MNPR), em face do Massacre da Praça da Sé, que figura hoje como narrativa fundadora do MNPR (Melo, 2013) e
} 
estudos para o universo da militância política em torno da reivindicação de direitos de homens e mulheres autodeclarados como moradores de rua, em situação de rua ou com trajetória de rua. Com pouca experiência pessoal em movimentos sociais e ainda com uma visão um tanto reducionista da mobilização política organizada (que concebia a luta destas pessoas sobretudo contra o Estado e jamais ao lado de seus agentes), adentrei nos espaços de discussão do MNPR-RS em 19 de junho de 2013. A partir de então, passei a fazer parte das reuniões semanais que ocorrem no Sindicato dos Municipários de Porto Alegre, com a presença de militantes em situação de rua e apoiadores do movimento, como assistentes sociais, monitores de albergues, psicólogos, enfermeiros, advogados, professores e estudantes universitários - todos, de certa forma, engajados na defesa dos direitos humanos.

Nos primeiros dois meses de trabalho de campo, sobretudo de participação nas reuniões do MNPR, não avancei muito além de uma posição confortável de quem timidamente observa e pensa que a simples presença lhe confere participação, concentrando-me muito mais em produzir anotações em diário de campo - na maioria das vezes redigidas na presença dos interlocutores. Mesmo assim, eu tinha em mente que essa situação em breve seria alterada, que seria uma questão de tempo, de insistência no contato, no vínculo, na presença, tal como ocorrera quando mergulhei no universo das relações estabelecidas no contexto não institucionalizado das ruas em Pelotas.

Mas no MNPR as trajetórias, as experiências e as dinâmicas de vinculações eram outras e exigiam novas posturas do pesquisador que, a princípio, eu não percebia ou protelava a saída do conforto analítico e da timidez pessoal. Além disso, outras questões pesavam para que essa mudança de fato ocorresse: eu também idealizava a forma como as vozes e o poder de fala e visibilidade eram dinamizados naquelas reuniões. Pelas poucas experiências que tive com a mobilização política durante a pesquisa de mestrado, eu imaginava que os que menos deveriam ter voz e poder de decisão e

como estopim para reivindicação e organização política destes sujeitos cuja força ganha amplitude a partir do decreto presidencial 7.053/09, que institui a Política Nacional para a População de Rua. O marco fundador mais institucionalizado do MNPR, contudo, localiza-se no cruzamento com o Movimento Nacional dos Catadores de Materiais Recicláveis (MNCR), cujas primeiras mobilizações em torno de associações e cooperativas remontam à década de 1970. Nesse processo, os representantes de articulações mais localizadas entre sujeitos "em situação de rua", inicialmente em São Paulo e Belo Horizonte (principalmente após o massacre de 2004) foram convidados a participar do $4^{\circ}$ Festival Lixo e Cidadania, convite que também estendeu-se a outras organizações que já ocorriam no Rio de janeiro, Bahia e Cuiabá. Neste encontro histórico, o MNPR é lançado e, nos anos subsequentes, multiplicado pelas principais capitais do país. 
influência sobre os assuntos e pautas discutidos eram os apoiadores, à época muitos dos quais eram também agentes institucionais e que, mesmo apoiando, deveriam muito mais escutar do que decidir o melhor caminho a seguir ou impor a última palavra aos que por muito tempo não tiveram espaços em que suas vozes e reivindicações fossem, de fato, ouvidas.

Para complicar mais um pouco, essa concepção que eu trazia de outros carnavais eram potencializadas por alguns sujeitos em situação de rua que justamente criticavam o comportamento de profissionais apoiadores do movimento. Alguns tencionavam a representação política centralizada, reiterando que todos ali presentes representavam o MNPR, porque todos sabiam o que era a rua e que as capacitações políticas, tão aclamadas como fundamentais para qualificar as discussões, eram descartáveis porque ninguém precisaria ser capacitado para falar sobre a rua e exigir seus direitos. Outros, algumas vezes, traziam à tona, em suas falas, as fronteiras simbólicas que as experiências de vida colocavam entre os militantes em situação de rua e os apoiadores: "nós sabemos o que é a rua, vocês nunca dormiram na rua".

O romantismo que guiou inicialmente o meu olhar também encontrava respaldo no desconforto que eu sentia ao me deparar com a "imposição" de regras, protocolos, ensinamentos sobre como se comportar, como trabalhar em grupo, como cultivar o respeito mútuo, a solidariedade e a escuta. Nas minhas primeiras impressões, quem mais falava e ensinava naquela reunião era o Estado, representado por seus agentes mas que, para além disso, eram também militantes com trajetórias respeitáveis em sindicatos e outros movimentos sociais. Eu ainda não conhecia o percurso de alguns apoiadores e também me faltavam reflexões que só viriam com o tempo, com as leituras e com as crises, que estavam só começando.

Ao longo dos primeiros meses de trabalho de campo, iniciei o diálogo com outros pesquisadores e acadêmicos envolvidos com projetos de pesquisa e extensão e que já haviam constituído vínculos e proximidades com os militantes, sobretudo pelo engajamento nas discussões tanto em pauta no MNPR-RS quanto em relação àquelas que os seus projetos propunham. Pedro Leite, Bruno Fernandes e Gabriela Jacobsen, acadêmicos em Ciências Sociais pela UFRGS, orientados pela antropóloga Patrice Schuch, (atual orientadora de minha pesquisa de doutorado) já participavam, desde o 
início de 2013, de um projeto de extensão ${ }^{9}$ e, vinculados ao Núcleo de Antropologia e Cidadania da UFRGS, desenvolviam algumas ações junto aos circuitos de atenção à população em situação de rua, assim como em seus coletivos de reivindicação de direitos em Porto Alegre, com a proposta de ampliar o debate e as conexões entre pesquisa, extensão e engajamento no trabalho antropológico. Passei a integrar essa equipe de pesquisadores alguns meses após o ingresso em campo, iniciando um diálogo importante e um processo de trocas e reflexões fundamentais para o desenvolvimento de algumas questões que conduzem minha pesquisa de doutorado. Mas foi também nessa aproximação que pude visualizar que a universidade não tinha a intenção de estar ali apenas em nome da pesquisa, pois anunciava uma contrapartida importante e uma vontade declarada de se colocar no debate público a partir de um compromisso com os que se mobilizavam por seus direitos, sobretudo na condição de apoiadores e colaboradores. E eu, sem muita experiência em movimentos sociais, continuava atuando sem muita exposição pública, detendo-me muito mais em ações práticas, como a escrita das atas e apoio na organização de alguns eventos. E mesmo tendo me integrado àquela equipe de pesquisadores, passando a me empenhar em algumas atividades, tentando dar um sentido ou ao menos uma praticidade à minha presença, eu ainda não conseguia avançar em contribuições ao debate coletivo no contexto da mobilização política.

Foi nesse aspecto que o mal-estar passou a se alimentar de alguns questionamentos: o que eu estava fazendo ali? Qual seria o meu papel enquanto antropólogo, principalmente no que se referia ao debate político? Como eu poderia contribuir e me posicionar se o meu olhar só via ambiguidades (como se o mundo assim não o fosse)? O olhar tão focado nos conflitos internos e na atuação dos apoiadores que pareciam lapidar e domesticar uma vontade de luta que vinha das ruas dificultava a visualização mais ampla da mobilização conduzida pelo MNPR-RS.

No conjunto, era como uma bola de neve: breves experiências pretéritas de contato com descontentamentos de interlocutores com abusos e desrespeitos vindos de agentes estatais e funcionários da rede sócio-assistencial; a minha insistência no interesse pela postura pedagógica dos apoiadores (monitores, assistentes sociais,

\footnotetext{
${ }^{9}$ Trata-se do projeto de extensão intitulado "Práticas de governo, Moralidades e Subjetividades nos circuitos de atenção às pessoas em situação de rua", do qual um dos objetivos principais é justamente colocar em questão a interface entre produção do conhecimento e engajamento político na interface com os direitos humanos. O projeto é coordenado e orientado pela Profa. Dra. Patrice Schuch, vinculada ao Programa de Pós-graduação em Antropologia Social e ao Departamento de Antropologia da Universidade Federal do Rio Grande do Sul.
} 
psicólogos, advogados); e o diálogo com outros pesquisadores com propostas importantes e posturas participativas - tudo isso produzia muitas coisas, e a principal delas era o sentimento de incapacidade em contribuir efetivamente com as pessoas (da forma como eu imaginava que deveria fazer), com as discussões e com a luta política mais ampla por direitos, respeito e dignidade.

Ao longo dos primeiros meses de 2014, as discussões sobre ações higienistas intensificaram-se nos debates realizados nas reuniões do MNPR-RS, sobretudo com a rede institucional que se acercava em função dos rumores de que a violência policial e a ação truculenta de algumas secretarias do Estado acirrar-se-iam com as proximidades da Copa do Mundo $^{10}$. Foi justamente nesse contexto em que rumores de higienização social, confinamento das pessoas em galpões ${ }^{11}$ e até crimes brutais contra os sujeitos que habitam o espaço público mobilizaram instituições a se aproximar e dialogar com o MNPR-RS, que me vi, de fato, em determinada situação que me fez perder a capacidade de refletir sobre o que estava fazendo, diante de um sentimento de indignação quase insuportável. O trecho de diário de campo a seguir detalha o que aconteceu naquele período:

Recebi um e-mail de Pedro Leite [estudante e apoiador do MNPR-RS] informando a denúncia da morte de Cláudio Luís Santos Fonseca, homem negro, de 39 anos, guardador de carros e em situação de rua. Segundo o e-mail, às seis horas da manhã do dia 23 de junho, nas proximidades do Parque da Redenção, cinco policiais teriam espancado Cláudio até a morte. A vítima teria sofrido afundamento de crânio, perfuração dos olhos e fratura de quatro costelas. Uma mulher teria testemunhado o fato da janela de seu apartamento e acionado a SAMU. Quando recebi a notícia fiquei paralisado, sem conseguir processar o ocorrido. Passei um dia inteiro tentando isolar o assunto da minha cabeça, mas comecei a pensar no que tinha me deixado tão deprimido e cheguei à conclusão de que não fora somente a forma como Cláudio

\footnotetext{
${ }^{10}$ Além da consolidação de uma rede institucional razoavelmente articulada em torno dos direitos da população de rua e contra a violência estatal, a força dos rumores de violência, higienização e confinamento culminou na conformação da Patrulha dos Direitos Humanos, uma ação que reuniu defensores, promotores, vereadores, advogados e agentes sociais diversos para percorrer as ruas da cidade coletando denúncias de abuso policial durante a noite em diferentes pontos de Porto Alegre. A ação ocorreu uma semana antes da Copa do Mundo e seus desdobramentos se concretizaram na constituição de um Grupo de trabalho intitulado "Moradores de rua e Segurança Pública" articulado pela Comissão de Defesa do Consumidor e Direitos Humanos (CEDECONDH) da câmara dos vereadores de Porto Alegre, além da constituição de um Comitê Intersetorial com a finalidade de elaborar uma política estadual de enfrentamento à violência institucional contra a população em situação de rua, encabeçado pela Secretaria Estadual de Justiça e Direitos Humanos. No mesmo período, o Conselho Nacional do Ministério Público (CNMP) lançou a "semana de mobilização nacional em defesa das pessoas em situação de rua", marcando a adesão do CNMP à campanha "Sou morador de rua e tenho direitos a ter direitos", lançada pelo Centro Nacional de Defesa dos Direitos Humanos das Pessoas em Situação de Rua e Catadores, no objetivo de incentivar a atuação do Ministério Público na defesa dos direitos destes segmentos.

${ }^{11} \mathrm{Um}$ dos primeiros rumores de violência estatal girou em torno da suposta criação de galpões, que estavam sendo edificados em Viamão, região metropolitana de Porto Alegre, para confinar pessoas em situação de rua durante todo o período da Copa do Mundo.
} 
perdera a vida, mas também a experiência com as instituições que se acercavam do MNPR-RS naquele momento, que já estavam me causando enorme e íntimo desconforto, justamente pelas contradições entre discursos de defesa de direitos, proclamado pela gama de agentes e instituições envolvidas, e as impossibilidades de avançar em pontos básicos, diante do assassinato consumado de uma forma tão brutal. Nesse momento, senti raiva e indignação! Acho que esses foram os sentimentos que predominaram em tudo que borbulhou dentro de mim quando percorri o trajeto das memórias do que vivenciei em campo até receber a referida notícia (Diário de Campo, 27/06/2014).

Naquele final de semana eu praticamente não dormi. Liguei para o IML várias vezes, mas sem nenhum sucesso na tentativa de identificar o registro de entrada do corpo no dia do ocorrido. Nenhum Cláudio teria dado entrada nos últimos dias. Uma reunião foi marcada dias depois na Câmara dos Vereadores, com o GT moradores de rua e segurança pública. Compareci à reunião com sangue nos olhos, relatando em público a minha indignação diante das descrições detalhadas do crime que recebera por email. A reunião, obviamente, girou em torno muito mais de explicitar as dificuldades em descobrir a veracidade do crime do que qualquer ação mais imediata de punição - como eu e a maioria dos integrantes do MNPR ali presentes queriam e reivindicavam no calor das emoções. Enquanto uma psicóloga, membro da CEDECONDH, montava um esquema no quadro branco para que todos visualizassem as etapas necessárias para a investigação do crime, eu levantei e me dirigi a um agente da Ouvidoria para perguntar se seria possível contatar a única testemunha do crime para que pudéssemos saber o local exato e, então, solicitar as filmagens de câmeras de vigilância. $\mathrm{O}$ agente respondeu que o foco das investigações deveria ser a conversa com a irmã de Cláudio - o que me deixou desconcertado, pois sabia que a suposta irmã não teria presenciado a suposta cena do crime e também não estava disposta, definitivamente, a fornecer qualquer informação. Ao final da reunião, converso com uma estudante de direito, apoiadora do MNPR-RS, e tento negociar a possibilidade de descobrirmos pelo menos o endereço da testemunha que teria acionado a SAMU na noite do crime.

$\mathrm{Na}$ semana seguinte, me inseri em um grupo formado por pesquisadores, militantes e apoiadores do MNPR para uma visita ao parque da Redenção, no intuito de conversar com algumas pessoas em situação de rua que poderiam ter conhecido Cláudio ou fornecer qualquer informação relevante. Naquela noite fria e chuvosa de junho, nos encontraríamos às 19 horas nas proximidades da Redenção. Eu, no entanto, cheguei uma hora mais cedo e adentrei sozinho no escuro do parque na tentativa de obter alguma informação sobre o assassinato ou qualquer paradeiro de Cláudio. Lembro que 
em uma parte mais deserta (pela Rua José Bonifácio), um jovem cujo rosto estava parcialmente coberto pelo capuz, analisou-me de cima-abaixo e, em seguida, olhou atentamente para os dois lados enquanto eu o inquiria sobre Cláudio. Rápida e ansiosamente ele informou que não sabia de nada, deixando claro nos gestos e no tom de voz que a minha presença ali não era bem-vinda - e foi quando senti a tensão daquela situação que me dei conta do que estava fazendo: adentrando um espaço no qual eu não era convidado e não conhecia os códigos. Tratei logo de me juntar ao grupo de militantes e apoiadores, conforme havíamos combinado.

Em reunião posterior, levamos estas informações para os demais integrantes do MNPR-RS. As informações eram tão desencontradas que produziam muitos ruídos e discussões. Ao final, duas grandes opiniões se consolidaram: ou de fato o crime teria acontecido e todo e qualquer vestígio de provas teria sido eliminado pela própria ação policial; ou, por algum motivo, aquela história toda teria sido inventada. $\mathrm{O}$ arremate final foi dado pela chegada repentina, na reunião, de um dos agentes da Ouvidoria Pública que estava participando das investigações. Segundo ele, a suposta irmã de Cláudio, interrogada pelo agente, teria inventado a história para tirar uma semana de folga da escola onde trabalhava como faxineira. Mesmo com essa informação, os integrantes do MNPR-RS não deixaram de celebrar o caminho que havíamos trilhado ao longo das investigações, as parcerias institucionais que foram firmadas e os aparatos de proteção mobilizados pela força dos rumores e histórias de violência estatal.

Sem a necessidade de explicitar aqui os desdobramentos, as análises e reflexões possíveis sobre o caso Cláudio, o importante é que, a partir dessa experiência, o meu envolvimento passou a ser emocional. Não se trata aqui, novamente, de pensar em uma conversão do pesquisador - como se outras situações não me haviam afetado antes, em diferentes situações de pesquisa com a população em situação de rua. Para este artigo, como já evocado nas experiências de Goldman e Favret-Saada, não basta estar afetado pelo interesse em estudar feitiçaria, blocos afro ou população em situação de rua, embora saibamos que o tema, o recorte e o objeto de nossas pesquisas não são escolhas aleatórias, pois dizem muito de nossas posições políticas, experiências individuais e trajetórias sociais. Mas, novamente, a afecção não diz respeito a essa parcialidade da relação entre pesquisador e universo de pesquisa. Sua potência revela-se nas relações involuntárias, quando somos capazes de levar a sério a participação, não apenas como antropólogos, mas como um sujeito que se permite afetar-se pela indignação, pela 
revolta, pela sede de justiça. Claro, é óbvio que isso poderia acontecer independente de minha posição de pesquisador. É possível supor que a maioria das pessoas se revolta ao se deparar com descrições de um assassinato brutal. Mas em um contexto de pesquisa, as relações de afecção, se alocadas com centralidade analítica, nos revelam muito mais do que uma reação normal a todos (ou quase todos) os mortais diante da violência contra pessoas historicamente desfavorecidos. Assim, não importa se a experiência que narrei é passível de afetar qualquer pessoa em qualquer situação; também não importa se, enquanto pesquisador, eu já estivesse afetado pelo campo ou pela simples escolha do tema de pesquisa (já está claro que não é desse tipo de afeto que estamos falando); o que importa, efetivamente, é que naquele contexto de pesquisa, onde supostamente atuo como antropólogo que deve desempenhar a observação participante, fui atingido em cheio por essas forças que me colocam no mesmo campo de intensidades que afetam os interlocutores. É a especificidade de um contexto de pesquisa em que se vivenciam experiências de afecção que permite conceder estatuto epistemológico a essas modalidades de participação em trabalho etnográfico.

Assim, no MNPR-RS, era preciso ocupar um lugar dentro daquela dinâmica de lutas e enfrentamentos, de conflitos, parcerias e ambiguidades (assim como FavretSaada precisou ocupar um lugar no sistema da feitiçaria). Foi imprescindível entrar, antes de tudo, numa comunidade de indignação, comunicando uma revolta e partilhando certos sentidos de justiça estimados coletivamente. Também assim eu pude visualizar o quanto os rumores referentes aos galpões de Viamão e ao assassinato de Cláudio fizeram com que os militantes em situação de rua e apoiadores mobilizassem uma rede de instituições que se empenharam tanto em atender as demandas por investigação quanto em dar visibilidade às ameaças de confinamento e violência (assim como Goldman precisou ouvir os tambores dos mortos para entender o som dos vivos). $\mathrm{O}$ caminho institucional foi trilhado a partir do caso Cláudio e um conhecimento da burocracia, dos termos, dos órgãos competentes, dos protocolos a serem seguidos, enfim, do funcionamento institucional de proteção, denúncia e investigação foi adquirido como um potente saber, que foi avaliado positivamente de forma unânime pelos integrantes do MNPR-RS. 
Obviamente que esse processo também não se refere somente ao pesquisador que, em sua trajetória de inserção em campo, valoriza sua subjetividade e as situações de crise e mal-estar. Se a comemoração das redes institucionais constituídas a partir do caso Cláudio se deu justamente em função do que estes novos parceiros poderiam contribuir para o MNPR-RS, eu também não estava imune do peso daquilo que eu representava: a universidade. Nessa condição, qual seria também a minha contribuição? E mais, se representando a universidade (e, portanto, o Estado!) fui capaz de mobilizar, de enfrentar, de investigar um crime quase por conta própria, de clamar justiça, então por que o incômodo com agentes estatais engajados em um movimento social e preocupados em contribuir a partir de suas experiências em outros coletivos de luta? Essa pergunta retórica mobiliza uma constatação que desmorona uma noção fixa do Estado e seus agentes, e permite considerar os sentimentos, afetos e moralidades que estavam em jogo na trama de relações firmadas entre apoiadores e pessoas em situação de rua no contexto do MNPR-RS.

Além do mais, aqui fica claro que levar a participação a sério é uma postura que pode ser compreendida, em alguns contextos, como uma posição ética, de comprometimento com os interesses e com os direitos dos grupos estudados. É possível pensar que ocupar um lugar no interior da mobilização política dinamizada por militantes em situação de rua e apoiadores é uma forma tanto de negociar a participação enquanto pesquisador, quanto de respeitar suas formas de luta por direitos - inclusive o direito de exigir que as instituições que deles se aproximam tenham alguma contrapartida, assumam responsabilidades na prática política e de alguma maneira contribuam positivamente para o reconhecimento e visibilidade de suas reivindicações. Sendo assim, parece que as relações de afecção estão longe de figurarem como exemplos de envolvimentos extremos de antropólogos com seus interlocutores (experiências que muitas vezes não são vistas com bons olhos, posto que ainda parecem significar a perda de controle analítico). Ao contrário, elas nos alertam para a conexão que possuem com a própria ética antropológica que, em contextos de luta política e reivindicação de direitos, é posta em relevo e desafia o trabalho etnográfico: em específicos universos de pesquisa, permitir-se afetar pelas mesmas forças que afetam os sujeitos de pesquisa é assumir, também, compromissos éticos e políticos. 
Assim, quando pensamos nos possíveis lugares que concedemos aos afetos no trabalho etnográfico, aprendemos que Favret-Saada só conseguiu identificar e compreender a feitiçaria ocupando um lugar nesse sistema de forças. Longe de algo estritamente estratégico, a afecção foi condição para acessar os discursos sobre os feitiços e para entender o próprio funcionamento das relações de feitiçaria. É interessante que, a um só tempo, a afecção lhe concede, a posteriori, reflexões tanto sobre um caminho para acessar a feitiçaria, quanto uma chave para compreender seu próprio funcionamento. Nesse último aspecto, não foi diferente com Goldman: ouvir os tambores dos mortos e impressionar-se com uma experiência religiosa não foi motivo para tratá-la apenas como tal. Foram os tambores dos mortos que, a partir de um processo posterior de reflexão e contato com lembranças e notas de campo, lhe esclarecem sobre a eficácia dos tambores dos vivos na construção de territórios existências e posicionamentos políticos. Em minha experiência, ser afetado pela brutalidade de um suposto assassinato, igualmente facilitou minha compreensão de que, sem ocupar um lugar na luta política da população em situação de rua, não haveria nada para observar. Disso decorre uma segunda via de compreensão: o movimento de reivindicação de direitos daquela população se inscreve numa dinâmica de trocas e negociações com os parceiros e as instituições que dele se aproximam, e o pesquisador, a universidade, o Estado não está imune a estas dinâmicas. É também assim que, em cenários de mobilização política, a afecção não envolve somente experiências de relações involuntárias que se ocupam de reposicionar o olhar e a experiência etnográfica em um plano simétrico ou reverso ao "mundo" dos interlocutores. Ela é chamada a existir pela própria força política dos sujeitos que dinamizam a luta e a garantia de seus direitos. Aqui, afecção e compromisso político com os coletivos estudados são irmãos gêmeos. 


\section{Considerações finais}

Ao longo deste artigo, argumentei em prol da potencialidade múltipla das relações de afecção vivenciadas em distintos contextos de pesquisa e que colocam em relevo alguns dilemas e críticas relacionadas à observação participante. A atenção à dimensão subjetiva, longe de encerrar-se num hipersubjetivismo, nos fornece elementos para pensar sobre diferentes caminhos de conjugação da observação e da participação na relação estabelecida com os interlocutores. Nesse sentido, as experiências discutidas acima tencionaram a própria onipresença dos objetivos acadêmicos em privilegiar a constituição de uma relação sistêmica entre a multiplicidade da vida social, na direção de descobrir uma "racionalidade encoberta" aos olhos do Outro.

Vimos que a experiência de afecção, nas três modalidades aqui apresentadas, reitera que os afetos que as subjazem não se referem aos sentimentos e às emoções sentidas pelo pesquisador - elas nos falam de uma maneira distinta de encarar a participação e de um lugar potente e central a ser concedido à situações e relações que escapam a qualquer apreensão imediata de compreensão sistemática. Além do mais, a operação na qual levamos a sério estas experiências nos leva a perceber que, ao buscar um lugar para os afetos no trabalho etnográfico, também estamos acessando dimensões antes ignoradas ou não muito claras sobre as formas como as pessoas agenciam seus universos de significação; sobre o quanto estes mesmos agenciamentos implicam o pesquisador e o forçam a repensar suas posições e engajamentos em campo, assim como suas concepções sobre método etnográfico; e, além disso, nos reportam a uma discussão sobre ética, comprometimento e participação política. É por tudo isso que repensar o lugar dos afetos na etnografia não é apenas uma questão de sensibilidade ou de demasiada atenção à subjetividade do pesquisador - ao contrário, a centralidade reflexiva dada à afecção é uma operação que amarra respeito e valorização da experiência alheia, abertura de canais de comunicação afetivos e posicionamento ético e político ao longo da pesquisa etnográfica. 


\section{Referências}

CLIFFORD, J. A experiência etnográfica: antropologia e literatura no século XX. Rio de Janeiro: Editora UFRJ, 1998.

CARDOSO DE OLIVEIRA, Roberto. O trabalho do antropólogo. São Paulo: Paralelo 15, 2000.

EVANS-PRITCHARD, E. Bruxaria, Oráculos e Magia entre os Azande. Rio de Janeiro: Jorge Zahar, 2005.

FAVRET-SAADA, Jeane. Les mots, la mort, les sorts. Paris: Gallimard, 1977. . Ser afetado. Cadernos de Campo, São Paulo, n.13, 2005.

FONSECA, Cláudia. Quando cada caso não é um caso. Pesquisa etnográfica e educação. Caxambu, Anped, 1998.

GOLDMAN, Marcio. Os tambores dos mortos e os tambores dos vivos. Etnografia, antropologia e política em Ilhéus - Bahia. Revista Antropologia, São Paulo, v.6, n.2, 2003.

Jeanne Favret-Saada, os afetos, a etnografia. Cadernos de Campo, São Paulo, n.13: 149-163, 2005.

GEERTZ, Clifford. A interpretação das Culturas. Rio de Janeiro: Zahar, 1978.

KOSBY, Marília. Se eu morrer hoje, amanhã eu melhoro: sobre afecção na etnografia dos processos de feitura da pessoa de religião no Batuque, em Pelotas/RS. Dissertação de mestrado em Ciências Sociais da Universidade Federal de Pelotas. Pelotas, 2009.

LARAIA, Roque de Barros. Cultura, um conceito antropológico. Rio de Janeiro: Zahar, 2009.

MALINOWSKI, Bronislaw. Argonautas do Pacífico Ocidental. São Paulo: Abril Cultura, 1984 (1922).

OLIVEIRA FILHO, João Pachecho. Pluralizando tradições antropológicas. Sobre um certo mal estar na Antropologia. Cadernos do Leme, v.1, 2009.

PORTO, Liliana. A ameaça do outro: magia e religiosidade no Vale do Jequitinhonha (MG). São Paulo: Attar, 2007.

SILVA, Vagner Gonçalves da. Na encruzilhada, com os antropólogos. Religião \& Sociedade. Rio de Janeiro, v. 24, n. 2, p. 28-60, 2005.

SAHLINS, Marshall. O "pessimismo sentimental" e a experiência etnográfica: por que a cultura não é um "objeto" em via de extinção (parte I). Mana, Rio de Janeiro, v. 3, n. 1, Apr. 1997

VELHO, Gilberto. Individualismo e cultura: notas para uma antropologia da sociedade contemporânea. Rio de Janeiro: Jorge Zahar, 1981.

VIVEIROS DE CASTRO, Eduardo. O nativo relativo. Mana, Rio de Janeiro, v. 8, n. 1, Apr. 2002.

WAGNER, Roy. A invenção da cultura. São Paulo: Cosac Naify, 2010.

Recebido em: 28/03/2015

Aprovado em: 24/05/2015 